\title{
Effect of Zinc and Iron on Growth of Amaranth (Amaranthus spp.) cv. Pusa Kiran
}

\author{
Girraj Prasad Jat ${ }^{1}$, J.R. Vadodaria ${ }^{1}$, K. Karthick ${ }^{1}$ and Sunil Nath ${ }^{2}$ \\ ${ }^{1}$ Department of Vegetable Science, College of Horticulture, S. D. Agricultural University, \\ Jagudan, Gujarat, India \\ ${ }^{2}$ Department of Soil Science, C. P. College of Agriculture, S. D. Agricultural University, \\ Gujarat, India \\ *Corresponding author
}

\begin{tabular}{|c|c|}
\hline & A B S T R A C T \\
\hline & \multirow{4}{*}{$\begin{array}{l}\text { This study was conducted during summer-2016 at Horticulture Instructional Farm, } \\
\text { Department of Horticulture, Chimanbhai Patel College of Agriculture, } \\
\text { Sardarkrushinagar Dantiwada Agricultural University, Sardarkrushinagar } \\
\text { (Gujarat). The results of field study showed minimum days taken for first cutting } \\
\text { ( } 29.75 \text { days) was recorded with individual application of zinc at } 0.30 \% \text {. Minimum } \\
\text { day taken for first cutting ( } 28.08) \text { was observed with individual application of iron } \\
\text { at } 0.45 \% \text {. The interaction of zinc at } 0.30 \% \text { and iron at } 0.45 \% \text { recorded minimum } \\
\text { days taken for first cutting (26.33) whereas interaction of zinc at } 0.45 \% \text { and iron } \\
\text { at } 0 \% \text { recorded minimum days taken for fourth cutting }(6.00) \text {. }\end{array}$} \\
\hline $\begin{array}{l}\text { Zinc, Iron, } \\
\text { Amaranth, } \\
\text { Foliar spray. }\end{array}$ & \\
\hline Article Info & \\
\hline $\begin{array}{l}\text { Accepted: } \\
\text { 18 February } 2017 \\
\text { Available Online: } \\
10 \text { March } 2017\end{array}$ & \\
\hline
\end{tabular}

\section{Introduction}

Amaranth is the most common leafy vegetable grown during summer and rainy season in India. It is popularly known as chaulai, is very nutritive and highly suitable crop for kitchen gardening and commercial cultivation. It is one of the cheapest leafy vegetables in tropical and subtropical parts of the country. It could be a very valuable source for combating under-nutrition and malnutrition. It fits well in crop rotations because of its short-duration and large yield per unit area. Amaranth is unique in many respects: it is easy to cultivate in kitchen garden or on large scale and respond very favourably to fertilizers and organic matter.
Recently, various evidences available indicated increasing research on micronutrient requirements in vegetables due to their critical importance in human diet. Hence, future emphasis on micronutrients may expand from their role in crop production, to their importance in the main staple foods with leafy vegetables in diets for sustaining human and animal health in view of bio-fortification.

The main objective of this study is to know the requirement of zinc and iron concentration for better and quick growth of Amaranth plant. 


\section{Materials and Methods}

This study was conducted during summer2016 at Horticulture Instructional Farm, Department of Horticulture, Chimanbhai Patel College of Agriculture, Sardarkrushinagar Dantiwada Agricultural University, Sardarkrushinagar (Gujarat). This experiment was laid out in randomized block design with factorial concept for two factors viz. zinc and iron. In this field study each factors with four levels $(0 \%, 0.15 \%, 0.30 \%$ and $0.45 \%)$ and three replications were used. In this present experiment zinc and iron were applied as foliar application of 7 DAS. Thus, there were total sixteen treatments under study. The crop was sown at a row distance of $30 \mathrm{~cm}$ and 10 $\mathrm{cm}$ plant to plant within row with a seed rate $2 \mathrm{~kg} / \mathrm{ha}$. A uniform application of recommended dose of NPK (100, 50, 20 $\mathrm{kg} / \mathrm{ha}$ ) through urea, SSP and MOP respectively were applied. The nutrients, 50 $\%$ dose of $\mathrm{N}$ and $100 \%$ dose of $\mathrm{P}$ and $\mathrm{K}$ were applied as basal dose. Remaining 50\% dose of $\mathrm{N}$ was applied in two equal splits as top dressing after second and third cutting. Growth characters such as days taken for first cutting and subsequent cuttings data were absorbed from each treatment and analysed by using the principles of 'Analysis of Variance' techniques as described by Panse and Sukhatme (1978).

\section{Results and Discussion}

\section{Effect of zinc on days taken for cuttings}

Data related to days taken for first, second, third and fourth cutting were recorded in table 1. Data showed that effect of different levels of individual application of zinc on days taken for first cutting was found significant, which were in range of 29.75 to 32.08 days. Significantly minimum days taken for first cutting (29.75) was found for individual application of zinc at $0.30 \%$ and it was at par with application of zinc at $0.45 \%$ and $0.15 \%$ whereas maximum days taken for first cutting (32.08) was recorded with individual application of zinc at $0 \%$. Effect different level of individual application of zinc was found not significant with days taken for second, third and fourth cutting.

\section{Effect of iron on days taken for cuttings}

The effect of different levels different levels of individual application of zinc of iron on days taken for first cutting was found significant, which were in range of 28.08 to 32.75 days. Minimum days taken for first cutting (28.08) was observed with individual application of iron at $0.45 \%$ and it was at par with application of iron at $0.30 \%$, whereas maximum days taken for first cutting (32.75) was with individual application of iron at $0 \%$. Effect of individual application of iron was found not significant with days taken for second, third and fourth cutting.

\section{Interaction effect of Zinc and Iron on days taken for cuttings}

The effect of interaction of Zinc and Iron was found significant for days taken for first and fourth cuttings whereas not significant results were recorded with days taken for second and third cuttings.

The effect of interaction of zinc and iron on days taken for first cutting data were recorded, which were in range of 26.33 to 35.33 days, minimum days taken for first cutting (26.33) was found with application of zinc at $0.30 \%$ and iron at $0.45 \%$, it was at par with treatments $\mathrm{T}_{12}, \mathrm{~T}_{15}$ and $\mathrm{T}_{4}$. Whereas maximum days taken for first cutting (35.33) was found with no application of zinc and iron, the effect of interaction of zinc and iron on days taken for fourth cutting data were recorded, which were in range of 6.00 to 9.33 days. Significantly minimum days taken for fourth cutting (6.00) was found with application of zinc at $0.45 \%$ and iron at $0 \%$ 
Table.1 Effect of zinc and iron on growth of Amaranth

\begin{tabular}{|c|c|c|c|c|}
\hline \multirow[t]{2}{*}{ Treatments } & \multicolumn{4}{|c|}{ Days taken for } \\
\hline & First cutting & $\begin{array}{l}\text { Second } \\
\text { cutting }\end{array}$ & Third cutting & Fourth cutting \\
\hline \multicolumn{5}{|c|}{ Levels of Zinc (Z) } \\
\hline$\left(\mathrm{Z}_{0}\right)-0.00 \%$ & 32.08 & 8.08 & 8 & 7.42 \\
\hline$\left(\mathrm{z}_{1}\right)-0.15 \%$ & 30.25 & 8.67 & 8.67 & 7.67 \\
\hline$\left(\mathrm{z}_{2}\right)-0.30 \%$ & 29.75 & 8.5 & 9.17 & 7.33 \\
\hline$\left(z_{3}\right)-0.45 \%$ & 30.25 & 7.75 & 8.75 & 6.67 \\
\hline S.Em \pm & 0.52 & 0.34 & 0.3 & 0.23 \\
\hline C.D. at 5\% & 1.49 & NS & NS & NS \\
\hline \multicolumn{5}{|c|}{ Levels of Iron (I) } \\
\hline$\left(\mathrm{i}_{0}\right)-0.00 \%$ & 32.75 & 8.5 & 8.5 & 7.67 \\
\hline$\left(\mathrm{i}_{1}\right)-0.15 \%$ & 32 & 7.75 & 8.42 & 7.33 \\
\hline$\left(i_{2}\right)-0.30 \%$ & 29.5 & 8.75 & 8.25 & 7.08 \\
\hline$\left(i_{3}\right)-0.45 \%$ & 28.08 & 8 & 9.42 & 7 \\
\hline S.Em \pm & 0.52 & 0.34 & 0.3 & 0.23 \\
\hline C.D. at 5\% & 1.49 & NS & NS & NS \\
\hline \multicolumn{5}{|c|}{ Interaction (ZxI) } \\
\hline $\mathrm{T}_{1}-\mathrm{z}_{0} \mathrm{i}_{0}$ & 35.33 & 7.67 & 8 & 9.33 \\
\hline $\mathrm{T}_{2}-\mathrm{z}_{0} \mathrm{i}_{1}$ & 34.33 & 5.67 & 8.33 & 7 \\
\hline $\mathrm{T}_{3}-\mathrm{z}_{0} \mathrm{i}_{2}$ & 29.67 & 9.67 & 7.67 & 6.67 \\
\hline $\mathrm{T}_{4}-\mathrm{z}_{0} \mathrm{i}_{3}$ & 29 & 9.33 & 8 & 6.67 \\
\hline $\mathrm{T}_{5}-\mathrm{z}_{1} \mathrm{i}_{0}$ & 30 & 10 & 9 & 7.33 \\
\hline $\mathrm{T}_{5}-\mathrm{z}_{1} \mathrm{i}_{1}$ & 30.33 & 9 & 8.67 & 8 \\
\hline $\mathrm{T}_{6}-\mathrm{z}_{1} \mathrm{i}_{2}$ & 30.67 & 8 & 8.33 & 8 \\
\hline $\mathrm{T}_{7}-\mathrm{z}_{1} \mathrm{i}_{3}$ & 30 & 7.67 & 8.67 & 7.33 \\
\hline $\mathrm{T}_{8}-\mathrm{z}_{2} \mathrm{i}_{0}$ & 32 & 8.33 & 8.33 & 8 \\
\hline $\mathrm{T}_{9}-\mathrm{z}_{2} \mathrm{i}_{1}$ & 31.33 & 8.67 & 8.33 & 7 \\
\hline $\mathrm{T}_{10}-\mathrm{z}_{2} \mathrm{i}_{2}$ & 29.33 & 9 & 9 & 7 \\
\hline $\mathrm{T}_{11}-\mathrm{z}_{2} \mathrm{i}_{3}$ & 26.33 & 8 & 11 & 7.33 \\
\hline $\mathrm{T}_{12}-\mathrm{z}_{3} \mathrm{i}_{0}$ & 33.67 & 8 & 8.67 & 6 \\
\hline $\mathrm{T}_{13}-\mathrm{z}_{3} \mathrm{i}_{1}$ & 32 & 7.67 & 8.33 & 7.33 \\
\hline $\mathrm{T}_{14}-\mathrm{z}_{3} \mathrm{i}_{2}$ & 28.33 & 8.33 & 8 & 6.67 \\
\hline $\mathrm{T}_{15}-\mathrm{Z}_{3} \mathrm{i}_{3}$ & 27 & 7 & 10 & 6.67 \\
\hline S.Em \pm & 1.03 & 0.8 & 0.68 & 0.53 \\
\hline C.D. at $5 \%$ & 2.28 & NS & NS & 2.11 \\
\hline C. V.\% & 5.84 & 16.73 & 13.68 & 12.7 \\
\hline
\end{tabular}

and it was found at par with treatments $T_{3}, T_{4}, T_{15}, T_{16}, T_{2}, T_{11}, T_{5}, T_{8}, T_{12}, T_{14}, T_{6}, T_{7}$ and $T_{13}$. Whereas maximum days taken for fourth cutting of amaranth (9.33) was found with treatment $\mathrm{T}_{1}$. 
The growth might be increased due to application of zinc, which influenced the cell division, meristematic activity of plant tissues and expansion of cells and formation of cell wall by activate synthesis of aromatic amino acids i.e. tryptophane, which is the primary precursor of auxin and stimulate the growth of plant tissues by cell elongation and cell division (Choudhary and Mukherjee, 1999 and Sarma et al., 2005). Iron is critical for chlorophyll formation and photosynthesis it might be reason for increasing growth of amaranth. These results are supported by Kotecha et al., (2011) in cabbage, Narayanmma et al., (2007) in cabbage and Rosta et al., (2015) in lettuce.

From the results of this investigation it can be concluded that individual foliar application of zinc at $0.30 \%$ and iron at $0.45 \%$ as well as combined foliar application of zinc at $0.30 \%$ and iron at $0.45 \%$ very beneficial for quick growth of amaranth plant.

\section{References}

Choudhary, D. and Mukharjee, S. 1999. Effect of boron and zinc concentration on growth yield and quality of cauliflower cv. Snowball-16, Haryana J. Horticultural Sci., 28(1-2): 119-120.

Kotecha, A.V. Dhruve, J.J. and Vihol, N.J. 2011. Effect of foliar application of micronutrients and growth regulators on growth and yield of cabbage (Brasicca oleracea L. var. capitata) cv. Golden Acre, Asian J. Horticulture, 6(2): 381384.

Narayanmma, M., Chiranjeevi, C.H. and Ahmmed, S.R. 2007. Effect of foliar application of micronutrients on the growth yield and nutrient content of cabbage (Brassica oleracea $L$ var capitata) Vegetable Sci., 34(2): 213214.

Panse, V.G. and Sukhatme, P.V. 1978. Statistical Methods for Agricultural Workers ICAR. Publ., New Delhi. Pp. 369.

Roosta, H.R., Jalali, M., Shahrbabaki,_and S. M.A.V. 2015. Effect of nano Fe-chelate, $\mathrm{Fe}-\mathrm{EDDHA}$ and $\mathrm{FeSO}_{4}$ on vegetative growth, physiological parameters and some nutrient elements concentrations of four varieties of lettuce (Lactuca sativa L.) in NFT system. Plant Nutri., 38(14): 2176-2184.

\section{How to cite this article:}

Girraj Prasad Jat, J.R. Vadodaria, K. Karthick and Sunil Nath. 2017. Effect of Zinc and Iron for Growth of Amaranth (Amaranthus spp.) cv. Pusa kiran. Int.J.Curr.Microbiol.App.Sci. 6(3): 1006-1009. doi: https://doi.org/10.20546/ijcmas.2017.603.118 